\title{
Difficult airway management - an old challenge: a case report
}

\author{
Ksenija Črnjar ${ }^{1}$, Sandra Kralik¹, Ivana Kerovec Sorić ${ }^{1}$, Ivan Bekavac ${ }^{1}$, Zoran Barčot ${ }^{1}$, Diana Butković ${ }^{1,2}$
}

Introduction: Obtaining a secured airway is a vital aspect during reconstructive surgery in patients with extensive post-burn mentosternal scar contractures. Such contractures can potentially lead to a "can't intubate, can't ventilate" scenario, otherwise rare but life-threatening situation. We present a case of successful management of a paediatric case of anticipated difficult airway due to burn injury.

Case description: A 14-year-old boy presented for repair of an extensive skin contracture of the neck, thorax and face due to mutilating scarring. The boy was treated for $80 \%$ burn caused by gasoline flame 14 months prior to this surgery. Burn healing and scarring resulted in massive distortion of the facial and cervical anatomy, all implying difficult airway with a high probability of "can't intubate, can't ventilate" situation. Flexible fiberoptic bronchoscope with loaded cuffed endotracheal tube Nº 6.0 was used for visualisation of vocal cords through the mouth in light sedation with spontaneous breathing. After visualisation of the vocal cords, fentanyl (Fentanyl, GlaxoSmithKline) and thiopental (Thiopental, Rotexmedica) were administered and the trachea was intubated at the first attempt. Balanced general anaesthesia was initiated and planned surgical procedure was successfully completed. The trachea was extubated on the first postoperative day without any complication.

Conclusion: Difficult paediatric airway and particularly "can't intubate, can't ventilate" situation is a problem associated with significant risks and complications. Anticipating a difficult airway, having a structured approach with appropriate preparation, and understanding of difficult airway management algorithms are essential for success.

Key words: AIRWAY MANAGEMENT; BURNS; INTUBATION

\section{INTRODUCTION}

Burn injury in children is a major epidemiological problem globally. Burns are the fourth most common type of trauma worldwide (1). Paediatric burn injuries are difficult to handle from the anaesthesiologist's point of view because they cause deranged pathophysiology and changes in airway anatomy. Airway issues in burns can be classified into two distinct groups of acute burn injury and chronic post-burn scar in need of reconstruction (2). In reconstructive surgeries involving patients with major scarring, considering that anatomical abnormality may be so extreme that difficult intubation should be expected, airway management is of vital importance. Due to the fact that mortality and morbidity are directly related to the ability to deliver oxygen to the patient, the airway must be managed with appropriate care and individualized approach (2). Post-burn hypertrophied scars and contractures of the head and neck region can se- verely restrict mouth opening and movements of the head and neck, thus leading to failed ventilation, unsuccessful intubation and airway emergency ("can't intubate, can't ventilate") (3). Furthermore, the use of muscle relaxants can exacerbate scar retraction due to traction of the scar tissue and loss of pulling action by the surrounding muscles, causing a potentially fatal loss of airway (2).

Noninvasive methods and devices intended to manage a difficult airway include awake intubation, video-assisted la-

\footnotetext{
'Department of Children's Anaesthesiology and Intensive Care, Zagreb Children's Hospital, Klaićeva 16, Zagreb, Croatia

${ }^{2}$ Faculty of Medicine, Josip Juraj Strossmayer University of Osijek, Osijek, Croatia
}

\section{Correspondence to:}

Ksenija Črnjar, MD, Zagreb Children's Hospital, Klaićeva 16, HR-10000 Zagreb, Croatia, e-mail: ksenija.crnjar@gmail.com

Primljeno/Received:28. 12. 2018., Prihvaćeno/Accepted:23. 4. 2019. 


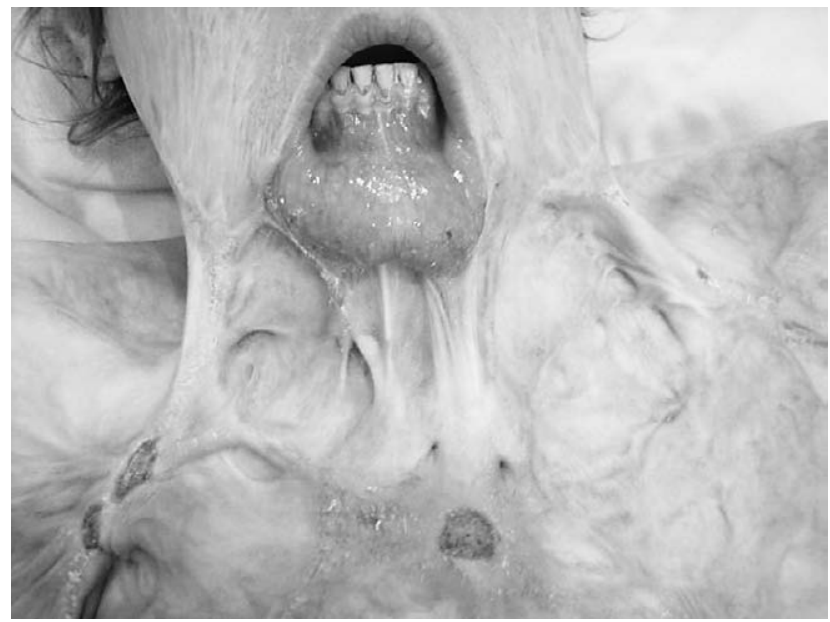

FIGURE 1. En face: Lip retraction, restricted mouth opening, hypertrophic scar extending over the neck

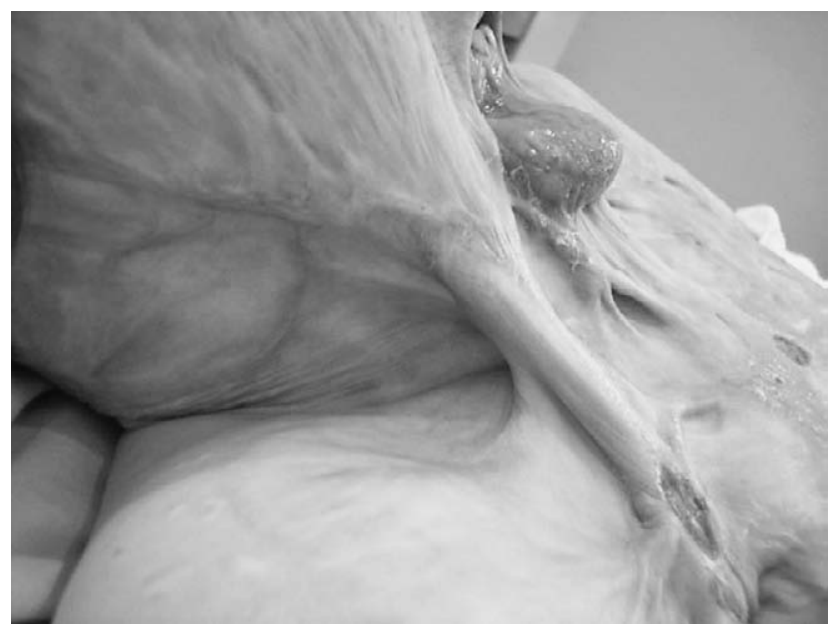

FIGURE 2. Right profile: hypertrophic scar, chin fusing with sternum, lip retraction

ryngoscopy, intubating stylets or tube-changers, supraglottic airway devices (laryngeal mask, laryngeal tube, I-gel, intubating laryngeal mask airway), laryngoscope blades of different design and various sizes, flexible fiberoptic bronchoscopes (FFBs), and light wands (4). FFBs are important means for performing awake tracheal intubation in patients with anticipated difficult airway with a success rate of $88 \%$ $100 \%$ according to the American Society of Anesthesiologists Task Force on Management of the Difficult Airway (4).

In a paediatric patient with difficult airway, performing an awake procedure may be challenging due to the lack of patient cooperation, therefore deep sedation or even anaesthesia is often necessary (5).

We describe successful management of a difficult airway in a paediatric burn patient, using FFB as an aid to tracheal intubation.

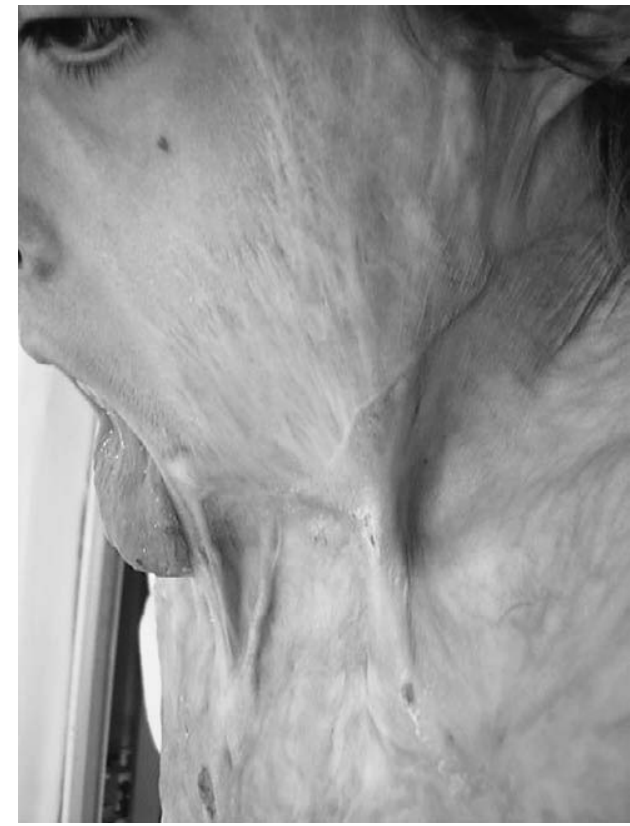

FIGURE 3. Left profile: eyelid ectropion, lip retraction, hypertrophic scar

\section{CASE REPORT}

A 14-year-old boy weighing $52 \mathrm{~kg}$ was treated in our hospital for third degree burn of $80 \%$ total body surface area, combined with an inhalational injury caused by gasoline flame. He was hospitalized for 11 months in total after the injury. He was initially treated in the intensive care unit for 36 consecutive days. For the first 7 days, he was analgosedated, orotracheally intubated and mechanically ventilated. At that time, different surgical procedures were performed (escharotomies of the left forearm and legs, necrectomies, skin transplantations sec Tiersch). Following discontinuation of analgosedation, he was extubated and resumed spontaneous ventilation without complication. In the further course of hospital stay, he underwent multiple anaesthesia procedures for various surgical operations (skin transplantations sec Tiersch, keratinocyte applications, and dressing changes). All these procedures were carried out without the need of endotracheal intubation (balanced anaesthesia with supraglottic airway devices or sedation with spontaneous breathing were performed).

The boy presented for repair of an extensive skin contracture of the neck, thorax and face due to mutilating scarring 14 months after the initial burn injury. Burn healing and scarring had resulted in massive distortion of the cervical spine, chin fusing with the sternum preventing neck movement, lip retraction with inability to close the mouth, bilateral eyelid ectropion and hypertrophic scar extending over the neck (Figure. 1-3). The nature of his scars had made neck flexion and extension impossible. Since evaluation of the 
parameters to determine difficult airway (thyromental distance, interdental distance, and the Mallampati score) was impossible, and also having in mind previous inhalational injury, magnetic resonance imaging of the head and neck was done preoperatively and it showed that the hypopharynx, larynx and trachea were of appropriate anatomy and dimensions for the patient's age. This airway was expected to be difficult regarding both ventilation and intubation. The airway management plans were made according to the Difficult Airway Algorithm by the American Society of Anesthesiologists (4). Plan A was to do FFB-guided oral intubation under light sedation, with the child breathing spontaneously and cooperating in the process. In case of the impossible visualization of the larynx, plan B was to do tracheotomy, therefore we had our otorhinolaryngologist on standby. A written informed consent was obtained from the parents. The patient was transported to the operation theatre without premedication. Standard anaesthesia monitors were applied (noninvasive blood pressure, electrocardiogram and pulse oxymetry) with oxygen administered through a nasal cannula $5 \mathrm{~L} / \mathrm{min}$. Difficult airway trolley was checked and prepared: FFB, laryngoscope with a selection of different spatulas and endotracheal tubes of various sizes were ready. Intravenous access was established and a drip of Hartmann's solution (B.Braun) was started along with sedation with midazolam (Dormicum, B.Braun) $5 \mathrm{mg}$. In view of the anticipated difficult ventilation and intubation, the child was encouraged to allow visualization of the larynx with FFB with loaded cuffed endotracheal tube 6.0 while lightly sedated and breathing spontaneously. Topical anaesthesia of the oral cavity and upper airways was achieved using 2\% lidocaine solution (Lidocaine 2\%, B.Braun) with spray-as-you-go technique. Following visualization of the vocal cords, fentanyl (Fentanyl, GlaxoSmithKline) $150 \mathrm{mcg}$ and thiopental (Thiopental, Rotexmedica) $400 \mathrm{mg}$ were administered, and after the child had been adequately anaesthetized, the trachea was intubated with cuffed endotracheal tube $\mathrm{N}^{\circ} 6.0$ railroaded over the FFB at the first attempt. After the correct position of the endotracheal tube had been reconfirmed by bronchoscopy and capnography, muscular relaxation with rocuronium (Esmeron, MSD) 30 mg was introduced and mechanical ventilation initiated. The airway management procedure was completed in fifteen minutes without adverse effects.

The operation of scar dissection and defect reconstruction cum Tiersch in balanced general anaesthesia was completed uneventfully. The trachea was extubated on the first postoperative day without any complication.

\section{DISCUSSION}

After the recovery from acute injury, burn patients are usually subjected to reconstructive surgery. Managing a patient with severe post-burn scarring of the neck and face is a challenging situation from the anaesthesiologist's point of view. These patients have many airway problems including restricted mouth opening, decreased oropharyngeal space, fibrotic scars in the neck and limited atlanto-occipital joint mobility, therefore they are not only very difficult to intubate but are also at a high risk of failed facemask ventilation $(3,6)$. In addition, history of inhalational injury may suggest tracheal stenosis, which could obstruct advancement of the endotracheal tube in the trachea (7).

It is essential that airway assessment is carried out preoperatively to evaluate the degree of difficulty, to plan primary strategy and to prepare alternative options to avoid airway emergency, the "can't intubate, can't ventilate" situation (5).

Assessment of the airway includes measuring thyromental distance, mouth opening (interdental) distance, the Mallampati score, and the flexion-extension mobility of the head and neck (8). In our patient, the face and neck were extremely distorted, causing difficulties with assessment of airway parameters, which is why the evaluation of the airway was done with magnetic resonance imaging.

In this case, the use of standard laryngoscope for intubation was considered impossible due to non-alignment of the oralpharyngeal-laryngeal axis. Also, ventilation via facemask was expected to be problematic if not even impossible. There are several choices recommended for such airway management, and they include awake FFB intubation, intubation with FFB via supraglottic devices after the induction of anaesthesia, pre-induction neck scar release under local anaesthesia, and/ or ketamine and elective tracheotomy (2). The use of laryngeal mask for release of a contracture and reconstruction surgery of the face and neck may prove to be dangerous since airway maintenance may be threatened in operations which require changing the position of the patient. Also, in such operations, the patient's head is covered with drapes and positioned away from the anaesthesiologist, thus securing the airway with an endotracheal tube being a safer approach, and that was our choice in this situation.

Awake intubation is considered the safest option for adult patients with known difficult airway. In contrast to adult anaesthesia, awake fiberoptic tracheal intubation in children is rarely a possibility, leaving the anaesthesiologist no choice but to manage the airway after induction of anaesthesia (4, 5). Maintenance of spontaneous breathing (avoiding muscular relaxation) until the airway is secured, as well as the use of FFB is suggested as the preferable technique in children with anticipated difficult airways $(5,6)$.

Our patient was motivated and cooperative, therefore awake oral FFB guided intubation was our main approach for securing the airway. The alternative plan for airway man- 
agement was to perform tracheotomy by our otorhinolaryngologist.

In conclusion, airway management of paediatric patients with severe head and neck burns may be very challenging because scarring can impair both mask ventilation and tracheal intubation, therefore induction by conventional methods may be disastrous. Proper preoperative assessment and multiple alternative plans to secure the airway are necessary for a positive outcome. Whenever an awake approach is feasible, it should be attempted, as it is the safest option for the patient.

\section{Abbreviations: \\ CICV - can't intubate, can't ventilate \\ FFB - flexible fiberoptic bronchoscope}

\section{REFERENCES}

1. Peck MD. Epidemiology of burn injuries globally (internet). UpToDate. Waltham, MA: UpToDate Inc. (updated: Jul 10, 2017).
Available from: https://www.uptodate.com/contents/epidemiology-of-burn-injuries-globally

2. Han TH, Teissler H, Han R J,D Gaines J, Nguyen T Q. Managing difficult airway in patients with post-burn mentosternal and circumoral scar contractures. Int J Burn Trauma. 2012;2:80-5.

3. Bajwa SS, Kaur J, Singh A, Singh G. Postburnfacial contractures in pediatric patients: Challenging aspects of difficult airway management. Int $J$ Health Allied Sci. 2012;1:186-9.

4. Apfelbaum JL, Hagberg CA, Caplan RA, et al. Practice guidelines for management of the difficult airway: an updated report by the American Society of Anesthesiologists Task Force on Management of the Difficult Airway. Anesthesiology. 2013;118:251-70.

5. Guimaraes J, Real C, Frada R, Orfao J, Machado H. A case of severe head and neck post-burn contractures: fiberoptic intubation through an I-gel laryngeal mask maintaining spontaneous ventilation. J Anesth Clin Res. 2015;6:573.

6. Guimaraes J, Frada R, Leal T, Orfao JM, Machado HS. Careful planning in a pediatric expected difficult airway in a specialized tertiary hospital: what can go wrong? A case report. J Anesth Clin Res. 2015;6:563.

7. Sabri A, Dabbous H, Dowli A, Barazi R. The airway in inhalational injury: diagnosis and management. Ann Burns Fire Disasters. 2017;30:24-29.

8. Russo SG, Becke K. Expected difficult airway in children. Curr Opin Anaesthesiol. 2015; 28:321-6.

\title{
Zbrinjavanje otežanog dišnog puta - vječni izazov: prikaz bolesnika
}

\author{
Ksenija Črnjar, Sandra Kralik, Ivana Kerovec Sorić, Ivan Bekavac, Zoran Barčot, Diana Butković
}

Uvod: Zbrinjavanje dišnog puta od vitalne je važnosti za bolesnika kod kojeg je indiciran rekonstruktivni zahvat nakon opsežnih opeklina lica i vrata. Kontrakture koje nastaju nakon takvih ozljeda mogu dovesti do nemogućnosti intubacije i ventilacije, što predstavlja rijetku ali životno ugrožavajuću situaciju. Prikazati ćemo uspješno zbrinjavanje pedijatrijskog bolesnika sa očekivano otežanim zbrinjavanjem dišnog puta.

Prikaz slučaja: Četrnaestogodišnji dječak sa opsežnom opeklinom lica, vrata i prsnog koša bio je predviđen za rekonstruktivni zahvat. Cijeljenje opekline, koja je nastala 14 mjeseci prije planiranog zahvata, rezultiralo je opsežnom kontrakturom i promjenom anatomije lica i vrata. Radi promijenjenih anatomskih odnosa bilo je očekivano da će zbrinjavanje dišnog puta biti otežano. Za vizualizaciju glasnica korišten je fleksibilni fiberoptički bronhoskop s pripremljenim endotrahealnim tubusom dokje bolesnik bio u plitkoj sedaciji i disao spontano. Nakon vizualizacije glasnica bolesnik je dobio fentanil (Fentanyl, GlaxoSmithKline) i tiopental (Thiopental, Rotexmedica) te je potom intubiran iz prvog pokušaja. Nastavljena je balansirana opća anestezija, planirani zahvat je uspješno dovršen. Bolesnikje ekstubiran prvi postoperativni dan bez ikakvih komplikacija.

Zaključak: Otežani dišni put u pedijatrijskih bolesnika je problem povezan s brojnim rizicima i komplikacijama. Prepoznavanje otežanog dišnog puta uz adekvatnu pripremu i poznavanje algoritama za zbrinjavanje otežanog dišnog puta ključno je za sigurnost bolesnika. 